\title{
IMPLEMENTASI ETIKA PELAYANAN PADA MINI MARKET DAN SWALAYAN PANYABUNGAN KABUPATEN MANDAILING NATAL GUNA MENCAPAI PROFIT YANG MAKSIMAL DITINJAU DARI EKONOMI ISLAM
}

\author{
Jureid \\ Sekolah Tinggi Agama Islam Negeri Mandailing Natal \\ jureid@stain-madina.ac.id
}

\begin{abstract}
Ethics must be a priority for the company or employees in every activity, including in achieving maximum profit. mini markets and supermarkets as a semimodern place should not only make profit as its main orientation but to priority ethics as its first step gaining maximum profit. The purpose of this study was to determine the implementation of ethics of service in mini markets and supermarkets in Panyabungan Mandailing Natal in order to achieve maximum profit and to overview the efforts to achieve profit in accordance with ethics of service in the view of Islamic economics. This research method is descriptive qualitative. This research concludes that mini markets and supermarkets in Panyabungan have implemented service ethics based on indicators of honesty values, speaking politely, skillfully, serving friendly, not prejudiced, serving responsibly, employees also apply helpful attitude, serve consumers well without favoritism and neatly dressed. Overview of Islamic Economics on the implementation of service ethics is in accordance with the principles of Islamic economics, namely the value of justice and balance in every practice. Justice, balance, honesty, help and the value of other sharia maqasid as Islamic economic values has been carried out with these indicators, all of which are in accordance with the principles of implementing Islamic economic values or Islamic law.
\end{abstract}

Keywords: ethics, service, mini market, islamic economy, supermarkets

\begin{abstract}
Abstrak
Etika harus menjadi prioritas perusahaan atau karyawan dalam setiap aktivitas, termasuk dalam usaha mencapai profit maksimal. mini market dan swalayan sebagai tempat jual beli secara semi modern tidak boleh hanya menjadikan profit sebagai orientasi utamanya tetapi harus mengutamakan etika sebagai langkah awal menuju profit maksimal. Tujuan penelitian ini adalah untuk mengetahui implementasi etika pelayanan pada mini market dan swalayan di Panyabungan Mandailing Natal guna mencapai profit maksimal dan mengetahui tinjauan ekonomi islam terhadap upaya mencapai profit tersebut sesuai dengan etika pelayanan menurut pandangan ekonomi Islam. Metode penelitian ini adalah deskriptif kualitatif. Penelitian ini menyimpulkan bahwa mini market dan swalayan di Panyabungan telah mengimplementasikan etika pelayanan dengan berdasarkan kepada indikator nilai-nilai kejujuran, berbicara yang sopan, cekatan, melayani dengan ramah, tidak berburuk sangka, melayani dengan penuh tanggung jawab, karyawan juga menerapkan sikap suka menolong, melayani konsumen dengan baik tanpa pilih kasih dan berpakaian yang rapi. Tinjauan Ekonomi Islam terhadap implementasi etika pelayanan telah sesuai dengan prinsip ekonomi Islam yaitu adanya nilai keadilan dan keseimbangan dalam setiap pengamalannya.
\end{abstract}


Keadilan, keseimbangan, jujur, tolong menolong dan nilai maqashid syariah lainnya sebagai nilai ekonomi Islam telah terlaksana dengan indikator tersebut, semuanya telah sesuai dengan prinsip pelaksanaan nilai-nilai ekonomi Islam atau syariat Islam.

Kata kunci: Etika, Pelayanan, Mini Market, Ekonomi Islam, Swalayan

\section{Pendahuluan}

Berusaha mencari penghidupan adalah kewajiban bagi setiap manusia. Hal tersebut tidaklah mengejutkan karena Islam menganjurkan umatnya untuk melakukan kegiatan usaha atau bisnis, dan hal tersebut juga diatur dalam AlQur'an. Konsep Al-Qur'an sangat komprehensif, sehingga parameternya tidak hanya menyangkut dunia, tetapi juga menyangkut urusan akhirat. Manusia harus mengubah keadaan mereka sehingga tidak mengalami kesulitan dalam kehidupan di dunia. Allah berfirman dalam Al-Qur'an surat Ar-Ra'd ayat 11 yang berbunyi:

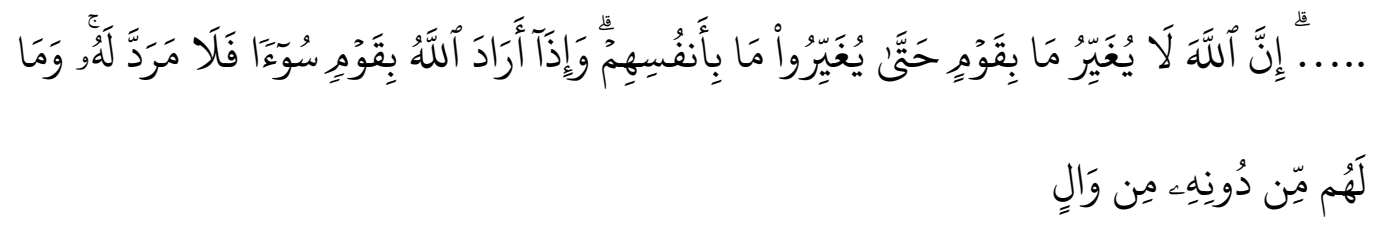

"Sesungguhnya Allah tidak merubah keadaan sesuatu kaum sehingga mereka merubah keadaan yang ada pada diri mereka sendiri. Dan apabila Allah menghendaki keburukan terhadap sesuatu kaum, maka tak ada yang dapat menolaknya; dan sekali-kali tak ada pelindung bagi mereka selain Dia."

Banyak cara yang dapat dilakukan oleh perusahaan dalam rangka meningkatkan jumlah penjualannya atau pelanggannya. Misalnya dengan memberikan pelayanan yang paling optimal, meningkatkan kualitas produk, menentukan harga yang sesuai dengan selera pasar, meningkatkan promosi penjualan, terus mengembangkan produk yang sesuai dengan keinginan dan kebutuhan pelanggannya atau dengan cara lainnya.

Etika atau ethics berasal dari kata yunani yaitu ethos artinya kebiasaan. Ia membicarakan tentang kebiasaan (perbuatan), tetapi bukan menurut arti tata adat, melainkan tata adab, yaitu berdasarkan kepada intisari atau sifat dasar manusia mengenai baik dan buruk, jadi dengan demikian etika adalah teori tentang perbuatan manusia ditimbang menurut baik buruk. 
Sikap atau etika disini meliputi sopan santun dalam melayani pembeli yang sesuai dengan yang dibenarkan Islam, menjaga sikap agar pembeli senang dan nyaman dalam memilih sesuatu yang ingin dibelinya, seperti tidak menunjukkan sikap curiga dan lain sebagainya. Dalam Islam, banyak dinyatakan dalam Arquran dan hadist tentang cara berbuat baik kepada sesama muslim antaranya adalah sabda Nabi SAW yang berbunyi:

"Bertakwalah engkau kepada Allah dimana pun engkau berada. Ikutilah (perbuatan) yang buruk dengan (perbuatan) yang baik, niscaya perbuatan yang baik itu akan menghapus perbuatan yang buruk dan, gaulilah manusia dengan budi pekerti yang baik. ${ }^{1}$

Secara sederhana, istilah service mungkin bisa diartikan sebagai "melakukan sesuatu bagi orang lain". Akan tetapi tidaklah mudah mencari padanan kata dalam bahasa Indonesia yang pas untuk istilah tersebut. Setidaknya ada tiga kata yang bisa mengacu pada istilah tersebut, yakni jasa, layanan, dan servis. Sebagai jasa service umumnya mencerminkan produk tidak berwujud fisik (intangible) atau sektor industri spesifik, seperti pendidikan, kesehatan, telekomunikasi, transportasi, asuransi, perbankan, perhotelan, kontruksi, perdagangan, rekreasi, dan seterusnya. ${ }^{2}$

Menurut Fandy Tjiptono dalam bukunya yang berjudul prinsip-prinsip total quality service mengatakan bahwa ada tiga kunci dalam memberikan layanan pelanggan yang unggul. Pertama, kemampuan memahami kebutuhan dan keinginan pelanggan. Kedua, pengembangan database yang lebih akurat daripada pesaing. Ketiga, pemanfaatan informasi-informasi yang diperoleh dari riset pasar dalam suatu kerangka strategik. ${ }^{3}$

Pelanggan menciptakan harapan-harapan layanan dari pengalaman masa lalu, cerita dari mulut ke mulut, dan iklan. Jika jasa yang dipresepsikan berada di bawah jasa yang diharapkan, pelanggan akan kecewa. Jika presepsi jasa memenuhi atau melebihi harapan mereka, mereka akan cenderung menggunakan penyedia tersebut lagi. ${ }^{4}$ Dari kutipan tersebut dapat disimpulkan bahwa pelanggan akan merasa puas apabila apa yang kita suguhkan sesuai dengan persepsi jasa memenuhi harapan mereka.

Peningkatan omset penjualan atau jumlah pelanggan merupakan aspek yang paling penting untuk dilakukan melalui pemberian pelayanan yang paling optimal 
karena dengan pelayanan yang optimal dapat memberikan kepuasan kepada pelanggan. Kepuasan ini akan menjadi promosi gratis dari pelanggan yang sudah merasakannya kemudian di sebarkannya ke calon pelanggan lainnya.

Di dalam memberikan pelayanan kepada pelanggan atau konsumen, karyawan harus bekerja secara professional dan terampil. Sifat profesionalisme digambarkan dalam Al-quran surah Al-Isra ayat 84 yang berbunyi:

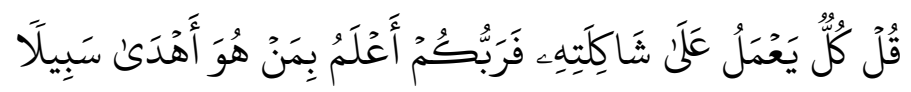

"Katakanlah: Tiap-tiap orang berbuat menurut keadaannya masingmasing. Maka Tuhanmu lebih mengetahui siapa yang lebih benar jalannya."

Pada ayat diatas, dikemukakan bahwa setiap orang beramal dan berbuat sesuai dengan kemampuan. Artinya, seseorang harus bekerja dengan penuh ketekunan dengan mencurahkan seluruh keahliannya. Jika seseorang bekerja sesuai dengan kemampuannya, maka akan melahirkan hal-hal yang optimal. Disamping itu dalam memberikan sebuah pelayanan yang baik, para karyawan dituntut untuk selalu bersikap ramah dan tersenyum. Dengan tersenyum (tabassum) ternyata akan melahirkan cinta, kasih sayang dan orang lain pun akan merasa lebih dihargai.

Kabupaten Mandailing Natal merupakan daerah otonom di Provinsi Sumatera Utara. Kabupaten Mandailing Natal ini merupakan hasil pemekaran dari Kabupaten Tapanuli Selatan. Pada tahun 1992, Dewan Perwakilan Rakyat Tingkat I Sumatera Utara memutuskan pemekaran wilayah Daerah Tingkat I Provinsi Sumatera Utara. Prioritas utama pemekaran wilayah itu adalah pembentukan Daerah Tingkat II Kabupaten Mandailing-Natal. Pada tanggal 23 November 1998, Pemerintah Republik Indonesia menetapkan Undang-Undang No. 12 Tahun 1998 yaitu Undang-undang tentang Pembentukan Kabupaten Daerah Tingkat II Toba Samosir Dan Kabupaten Daerah Tingkat II Mandailing Natal, dan secara formal diresmikan oleh Menteri Dalam Negeri pada tanggal 9 Maret 1999. Berdasarkan Undang-undang No. 12 Tahun 1998, Kabupaten Mandailing Natal yang dikenal dengan sebutan Madina, terdiri dari atas 8 (delapan) kecamatan.

Berbagai pusat perekonomian masyarakat dan sumber-sumber pendapatan dibangun dan dikembangkan agar mampu membiayai pembangunan. 
Hal ini dilakukan untuk mempercepat pertumbuhan ekonomi, mewujudkan masyarakat yang makmur dan sejahtera melalui pemberdayaan ekonomi masyarakat, peningkatan pelayanan terhadap masyarakat dan peningkatan peran serta masyarakat dalam segala bidang termasuk bidang ekonomi dalam hal pemenuhan kebutuhan sehari-hari masyarakat yang semakin besar.

Perkembangan Mini Market memang menjadi tren baru bagi masyarakat Panyabungan dalam berbelanja kebutuhan pokok dan kebutuhan sehari-hari. Hal ini juga didukung oleh perubahan pola pikir masyarakat Panyabungan yang ingin mencoba berbelanja kebutuhan sehari hari di pasar semi-modern tersebut, dengan cara melayani diri sendiri serta dilayani pihak lain pada mini market tersebut. Panyabungan sebagai pusat ibukota memiliki jumlah mini market yang cukup banyak bila dibandingkan dengan rasio jumlah penduduknya berdasarkan jenis kelamin berjumlah $\mathrm{L}+\mathrm{P}=84.153 .{ }^{5}$ Mini market yang dimaksud adalah mini market yang telah memiliki karyawan lebih dari dua orang sebagai pelayan pada pusat perbelanjaan tersebut. Adapun Mini market atau Swalayan yang menjadi tempat penelitian dan berdasarkan kategori yang disebutkan di atas adalah sebagai berikut:

Tabel 1 Nama-nama Mini Market di Panyabungan Mandailing Natal

\begin{tabular}{|c|l|l|}
\hline NO & \multicolumn{1}{|c|}{ NAMA MINI } & \multicolumn{1}{c|}{ ALAMAT } \\
\hline 1 & Manindo Mart & Kayu Kati Panyabungan \\
\hline 2 & Indomart & Sipolu-polu Panyabungan \\
\hline 3 & Toko Ajis (Mini Market) & Pasar Lama Panyabungan \\
\hline 4 & Mini Market Dalan Lidang & Dalan Lidang Panyabungan \\
\hline 5 & Madina Swalayan & Sipolu-polu Panyabungan \\
\hline 6 & Mini Market Syariah & Dalan Lidang Panyabungan \\
\hline 7 & Madina Thursina & Dalan Lidang Panyabungan \\
\hline 8 & Aqila Mart & Sipolu-polu Panyabungan \\
\hline 9 & Mini Market Panyabungan Tonga & Panyabungan Tonga \\
\hline 10 & Go Belanja Swalayan & Kayu Jati Panyabungan \\
\hline
\end{tabular}

Sumber: Data diolah Penulis, 2020

Dalam rangka untuk mancapai target keuntungan atau laba pusat pembelanjaan yang disebutkan di atas, tentu mereka harus memberikan pelayanan yang baik dan prima kepada kosumen, serta rasa aman. Salah satu usaha yang paling ditekankan perusahaan untuk meningkatkan penjualan dengan memberikan pelayanan yang optimal kepada konsumen dengan bersikap sebaik mungkin 
dalam memberikan pelayanan supaya konsumen merasa nyaman dalam berbelanja.

\section{Kajian Teoritis}

\section{Pengertian Etika}

Etika atau ethics berasal dari kata yunani yaitu ethos artinya kebiasaan. Ia membicarakan tentang kebiasaan (perbuatan), tetapi bukan menurut arti tata adat, melainkan tata adab, yaitu berdasarkan kepada intisari atau sifat dasar manusia mengenai baik dan buruk, jadi dengan demikian etika adalah teori tentang perbuatan manusia ditimbang menurut baik buruk. ${ }^{6}$ Etika juga dapat diartikan serangkaian tindakan berdasarkan kebiasaan yang mengarah kepada perbuatan benar atau salah. Sebagai penjual jasa, masyarakat membutuhkan pelayanan dan perlakuan yang menyejukan hati mereka melalui sikap ramah dan sopan para karyawan. Sedangkan etika berarti kesantunan yaitu sikap bathin, prinsip hidup, pandangan moral serta bisikan hatinurani. ${ }^{7}$ Adapun ketentuan yang diatur dalam etiket secara umum antara lain: sikap dan perilaku, penampilan, cara berpakaian, cara berbicara, gerak gerik, cara bertanya, dan lain- lain. ${ }^{8}$ Adapun sikap dan perilaku yang terpuji (mahmudah) antara lain: berlaku jujur (al-amanah), memelihara diri (al-iffah), perlakuan baik (ihsan), kebenaran ('adl), keberanian (syaja'ah), dan malu (haya').

\section{Dasar hukum Etika}

Dalam Al-Quran telah dijelaskan terkait perbedaan antara yang baik dengan yang buruk, bahwa manusia mengerti akan apa yang baik dan apa yang buruk, bahwa ia dapat membedakan antara keduanya dan selanjutnya mengamalkannya, adalah suatu kenyataan yang tidak bisa dibantah. Pengertian itu tidak dicapainya melalui pengalaman, akan tetapi ia adalah fitrah.

Pada ketika itu Allah lalu memberikan pengertian tersebut kepadanya. Jadi pengertian baik buruk merupakan tanggapan pembawaan manusia. Dan ia telah ada secara apriori pada diri manusia. Dan hal ini dijelaskan dalam Al-Quran dengan dasar hukumnya Surah Al Maidah ayat 100:

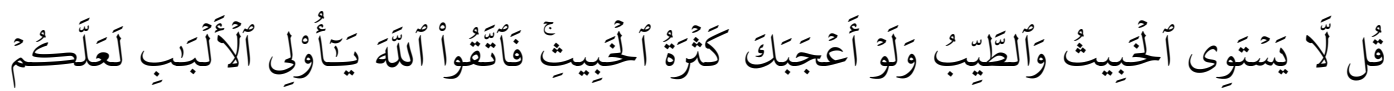


banyaknya yang buruk itu menarik hatimu, maka bertakwalah kepada Allah hai orang-orang berakal, agar kamu mendapat keberuntungan."

Pembelajaran yang dapat diambil dari ayat di atas adalah kebaikan atau kita sebut etika adalah lebih baik dijadikan pedoman dalam setiap sisi kehidupan manusia sebagai pengawet citra padanya.

Berdasarkan beberapa teori di atas, dapat disimpulkan bahwa pelayanan merupakan suatu kegiatan atau proses yang berlangsung secara terus menerus dalam interaksi antara seseorang dengan orang lain dan menyediakan kepuasan pelanggan. Dalam rangka menjaga dan meningkatkan kepercayaan pelanggan, setiap pengusaha perlu menjaga citra positif produk dan perusahaan di mata pelanggannya atau masyarakat umumnya. Citra ini dapat dibangun melalui kualitas produk, kualitas pelayanan, dan jaminan keamanan. Tanpa citra yang positif, kepercayaan yang sedang dan akan dibangun tidak akan efektif.

Menurut Kasmir bahwa untuk meningkatkan citra perusahaan, wirausahawan perlu menyiapkan sumber daya manusia (karyawan) yang mampu menangani keinginan dan kebutuhan pelanggannya. Karyawan yang diharapkan dapat melayani keinginan dan kebutuhan pelanggan kita sebut customer service (CS) atau ada juga yang menyebutnya service assistance (SA). ${ }^{9}$ Berdasarkan pendapat di atas, dapat dijelaskan bahwa pelayanan sangat memegang peranan penting dalam membangun citra positif bagi sebuah perusahaan khususnya yang berkaitan dengan pelayanan jasa. Semakin baik pelayanan yang diberikan oleh perusahaan maka akan memberikan dampak positif bagi kemajuan perusahaan itu sendiri.

Sebagaimana dikemukakan oleh Kotler bahwa ada enam pendekatan untuk meningkatkan pelayanan yakni sebagai berikut: ${ }^{10}$

1. Mengharuskan para penyedia jasa bekerja lebih keras dengan keahlian yang lebih tinggi.

2. Meningkatkan pelayanan dengan melepaskan beberapa mutu.

3. Mengindustrialisasikan pelayanan dengan menambahkan peralatan dan melakukan standarisasi produksi.

4. Mengurangi pelayanan dengan melakukan suatu pemecahan produk.

5. Mendisain pelayanan yang lebih efektif.

Untuk menarik langganan dan mempertahankan langganan lama, suatu 
Perusahaan harus mengadakan pelayanan dengan baik dan teratur. Hal tersebut perlu dilakukan oleh suatu perusahaan, karena sikap pelanggan adalah dinamis jika ia menyukai barang atau jasa dari suatu perusahaan dan berhak menentukan pilihan yang cocok bagi mereka. Budaya pelayanan yang harus dikembangkan dalam setiap organisasi harus meliputi dua tingkatan, yaitu: ${ }^{11}$

1. Pelayanan yang harus diutamakan. Pelayanan terdiri dari kehandalan (reliability), daya tanggap (responsivness), jaminan (assurance), empati (empathy) dan bukti fisik (tangible).

2. Nilai nilai dasar yang harus dimiliki anggota, terdiri dari nilai kejujuran, Hormat, nilai kegembiraan, kerjasama dan kemauan.

\section{Dasar-dasar Pelayanan}

Beberapa hal yang harus diperhatikan karyawan ketika memberikan pelayanan kepada kosumen yaitu:

1. Berpakaian dan berpenampilan yang rapi dan bersih.

2. Percaya diri, bersikap akrab dan penuh dengan senyum.

3. Menyapa dengan lembut dan berusaha menyebutkan nama jika sudah kenal.

4. Tenang, sopan, serta tekun mendengarkan setiap pembicaraan.

5. Berbicara dengan bahasa yang baik dan benar.

6. Jangan menyela atau memotong pembicaraan.

7. Mampu menyakinkan pelanggan atau nasabah serta memberikan kepuasan.

8. Jika tidak sanggup menangani permasalahan yang ada, minta bantuan. Artinya jika ada pertanyaan atau permasalahan yang tidak sanggup dijawab atau diselesaikan oleh karyawan, maka harus meminta bantuan kepada petugas lain yang mampu.

Adapun larangan dalam memberikan pelayanan secara umu dilakukan oleh berbagai perusahaan antara lain ${ }^{12}$ dilarang berpakaian sembarangan, dilarang melayani konsumen atau tamu sambil makan, dilarang melayani konsumen atau tamu sambil mengobrol, dilarang menampakkan wajah yang tidak menyenangkan, dilarang berdebat atau menyanggah, dilarang meninggalkan nasabah, dilarang berbicara terlalu keras atau lemah, dan dilarang keras meminta imbalan atau janjijanji.

\section{Kualitas Pelayanan}


Budaya adalah segala nilai, pemikiran, serta simbol yang mempengaruhi perilaku, sikap, kepercayaan serta kebiasaan seseorang dalam masyarakat. ${ }^{13}$ Pencipta budaya adalah seorang pemimpin, setiap pemimpin mempunyai visi dan misi tertentu yang kemudian disebarkan pada karyawan. Seorang pemimpin memberi contoh, kemudian diikuti oleh bawahan. Akhirnya kebiasaan-kebiasaan itu akan menjadi budaya jika semua mempraktekkannya baik pimpinan dan bawahannya. ${ }^{14}$ Kualitas pelayanan berhubungan erat dengan pelayanan yang sistematis dan komprehensif yang lebih dikenal dengan konsep pelayanan prima. Tujuan dari pelayanan pada dasarnya adalah memuaskan (satisfaction) masyarakat. Untuk mencapai kepuasan itu dituntut kualitas pelayanan prima yang tercermin dari:

1. Transparansi, yakni pelayanan yang bersifat terbuka, mudah dan dapat diakses oleh semua pihak yang membutuhkan dan disediakan secara memadai serta mudah dimengerti.

2. Akuntabilitas, yakni pelayanan yang dapat dipertanggung jawabkan sesuai dengan ketentuan peraturan perundang-undangan

3. Kondisional, yakni pelayanan yang sesuai dengan kondisi dan kemampuan pemberi dan penerima pelayanan dengan tetap berpegang pada prinsip efisiensi dan efektivitas.

4. Partisipatif, yaitu pelayanan yang dapat mendorong peran serta masyarakat dalam menyelenggarakan pelayanan _ltern dengan memperhatikan aspirasi, kebutuhan, dan harapan masyarakat.

5. Kesamaan hak, yaitu pelayanan yang tidak melakukan diskriminasi dilihat dari aspek apapun khususnya suku, ras, agama, golongan, status sosial, dan lain-lain.

6. Keseimbangan hak dan kewajiban, yaitu pelayanan yang mempertimbangkan aspek keadilan antara pemberi dan penerima pelayanan. ${ }^{15}$

Selain peningkatan kualitas pelayanan melalui pelayanan prima, pelayanan yang berkualitas juga dapat dilakukan dengan konsep layanan sepenuh hati. Layanan sepenuh hati ini yakni yang berasal dari diri sendiri yang mencerminkan emosi, watak, keyakinan, nilai, sudut pandang, dan perasaan. Dalam melakukan bisnis perlu adanya rambu-rambu yang ditegakkan secara jelas dan mengikat semua pelaku bisnis produsen, distributor dan konsumen. Semua ini ditujukan 
agar nilai kemanusian bisa menjadi ltern yang terintegrasi dalam praktek ekonomi sehari-hari. Rambu itu adalah etika bisnis yang berisi aturan untuk dipatuhi oleh para pelaku bisnis agar tercipta keserasian dan ketentraman dalam menjalankan peranan masing-masing. ${ }^{16}$

\section{Etika Pelayanan}

Etika pelayanan untuk berbagai kegiatan perlu ada ketentuan yang mengaturnya. Ketentuan ini dibuat agar semua komponen yang berhubungan dengan pelayanan dapat menunjang satu sama lainnya. Artinya apabila salah satu aspek diabaikan, pelayanan dari komponen lainya menjadi tidak berguna. Adapun ketentuan yang diatur dalam etika secara umum meliputi Sikap dan perilaku, Penampilan, Cara berpakaian, Cara berbicara, Gerak-Gerik, Cara bertanya. ${ }^{17}$

\section{Etika Pelayanan Dalam Islam}

Sikap melayani adalah salah satu prinsip bisnis Islami. Rasulullah mengatakan, "Saidul kaum khalimuhum (pengurus atau pengusaha itu adalah pelayan bagi pelanggannya)." Karena itu, sikap murah hati, ramah, dan sikap melayani merstilah menjadi bagian dari kepribadian semua karyawan dalam

bekerja. ${ }^{18}$ Seorang pelaku bisnis muslim diharuskan untuk berperilaku dalam bisnis mereka sesuai yang dianjurkan Al-Quran dan sunnah. Sopan santun adalah fondasi dasar dan inti dari kabaikan tingkah laku, dan ia juga merupakan dasar dari jiwa melayani (servis) dalam bisnis. Sifat ini sangat dihargai dengan nilai yang tinggi, dan bahkan mencakup semua sisi hidup manusia. ${ }^{19}$

Al-Quran telah memerintahkan dengan perintah yang sangat ekspresif agar kaum muslimin bersifat lembut dan sopan manakala dia berbicara dengan orang lain. Pada suatu ketika Rasulullah merasa sangat bangga dengan derma dalam bentuk harta, namun pada suatu saat yang lain beliau juga mengatakan, "sebaikbaik derma adalah dermanya lidah", kita juga diperintahkan untuk berlaku adil dan ramah dalam semua bentuk pergaulan sebagaimana diperintahkan untuk menghindari segala tindakan sekiranya akan menyulitkan orang lain. Kedua hal terakhir yang dijelaskan dalam Al-Quran, merupakan bagian dari servis dalam dunia bisnis. Melayani dari kesulitan bahkan membebaskannya sama sekali. Itulah konsep servis (pelayanan) dalam muamalah Islami. $^{20}$ Etika bisnis Nabi Muhammad SAW adalah nilai spiritual, humanisme, kejujuran keseimbangan, dan semangatnya untuk memuaskan mitra bisnisnya. Nilai-nilai di atas telah 
melandasi tingkah laku dan sangat melekat serta menjadi ciri kepribadian sebagai Manajer profesional. Implementasi bisnis yang ia lakukan berporos pada nilainilai tauhid yang diyakininya. Secara prinsip, ia telah menjadikan empat pilar berikut ini sebagai dasar transaksi ekonominya.

\section{Tujuan dan Manfaat Etika Pelayanan}

Tujuan dari etika antara lain adalah untuk persahabatan dan pergaulan, menyenangkan orang lain, membujuk pelanggan, mempertahankan pelanggan, membina dan menjaga hubungan, berusaha menarik pelanggan ${ }^{21}$. Sedangkan manfaat etika antara lain dengan etika dapat meningkatkan rasa percaya diri bagi seluruh karyawan, dihormati dan dihargai, disegani dan disenangi. Pada dasarnya setiap perbuatan yang baik tentu memiliki tujuan yang baik, sehingga akan memberikan manfaat yang baik pula. Disamping memiliki tujuan etika juga memberikan manfaat yang cukup banyak bagi perusahaan apabila dilakukan dengan sungguh-sungguh.

\section{Prinsip Ekonomi Islam}

Prinsip-prinsip ekonomi Islam yang merupakan bangunan ekonomi Islam didasarkan atas lima nilai universal yakni : tauhid (keimanan), 'adl (keadilan), nubuwwah (kenabian), khilafah (pemerintah) dan ma'ad (hasil). Kelima nilai ini menjadi dasar inspirasi untuk menyusun teori-teori ekonomi Islam. ${ }^{22}$ Namun teori yang kuat dan baik tanpa diterapkan menjadi sistem, akan menjadikan ekonomi Islam hanya sebagai kajian ilmu saja tanpa member dampak pada kehidupan ekonomi. Karena itu, dari kelima nilai-nilai universal tersebut, dibangunlah tiga prinsip derivatif yang menjadi ciri-ciri dan cikal bakal sistem ekonomi Islami. Ketiga prinsip derivatif itu adalah multitype ownership, freedom to act, dan social justice. Tata aturan syariah dalam ekonomi yang berasal dari Al-Quran dan Hadist itu memuat prinsip atau dasar umum sebagai landasan dan dasar pengembangan Ekonomi Islam. Prinsip ini membentuk keseluruhan kerangka Ekonomi Islam, yang jika diibaratkan sebagai sebuah bangunan dapat divisualisasikan pada gambar rancang bangun Ekonomi Islam dibawah ini: 


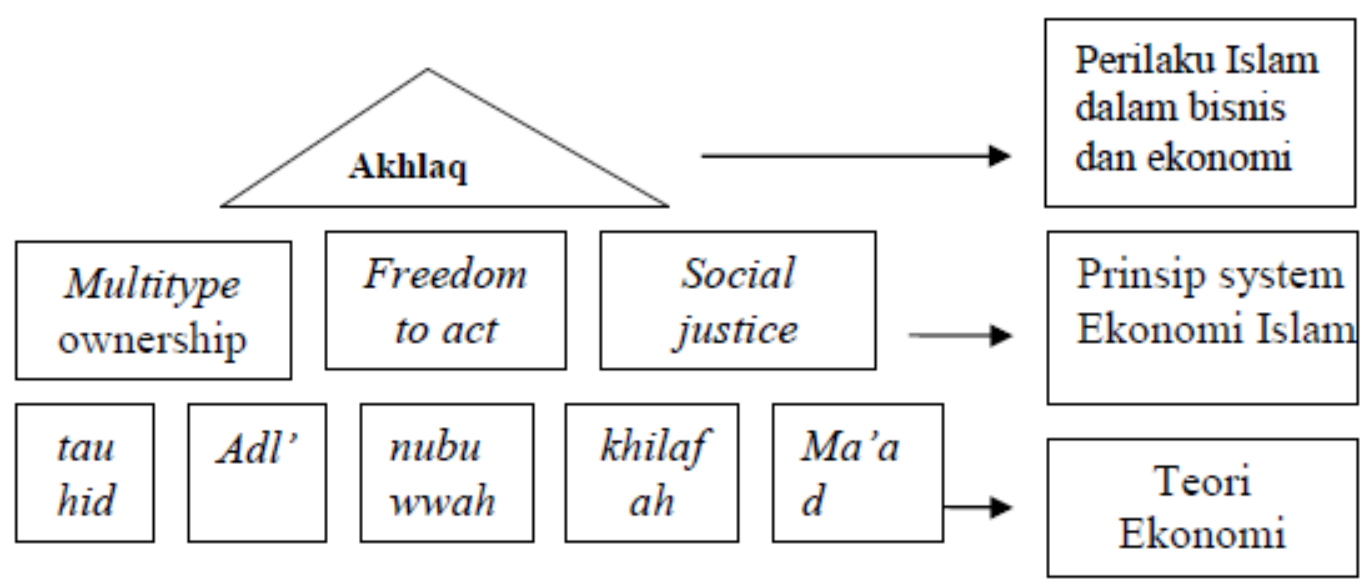

Gambar 1. Bangunan Ekonomi Islam

Terdapat tiga komponen dalam rancang bangun ekonomi Islam yaitu teori ekonomi Islam, prinsip sistem ekonomi Islam, dan perilaku Islam dalam bisnis dan ekonomi. Ketiga komponen ini jika diterapkan dengan benar maka akan terbangun suaatu bangunan perekonomian yang relevan dan tidak keluar dari syriat islam. ${ }^{23}$ Sistem ekonomi Islam memiliki prinsip keadilan dan moral yang menyelaraskan kepentingan individu dan masyarakat, yang akan memberi kesejahteraan dan kemakmuran bagi bangsa dan negara. Ekonomi Islam bertujuan untuk memungkinkan manusia memenuhi kebutuhan hidupnya yang disyariatkan dalam Syariah Islam. Keunggulannya terletak pada prinsip yang mendasarinya yaitu spirit dan moral.

\section{Ciri-Ciri Ekonomi Islam}

Ekonomi Islam mempunyai ciri-ciri khusus, yang membedakan dengan sistem ekonomi lainnya. Dapat dikemukakan beberapa ciri-ciri Ekonomi Islam sebagai berikut: ${ }^{24}$

1. Ekonomi Islam merupakan bagian dari sistem menyeluruh

Ekonomi Islam tidak terlepas dari akidah dan syariah. Karena system Ekonomi Islam adalah bagian dari syariah itu sendiri, dan hubungan dengan akidah selaku dasar keyakinan. Hubungan ekonomi dengan akidah dapat di lihat misalnya dalam pandangan Islam bahwah segala yang ada di alam ini digariskan untuk patuh dan mengabadi ke pada Allah. Adanya hubungan Ekonomi Islam dengan akidah dan syariat Islam itulah yang menyebabkan mengapa kegiatan ekonomi dalam Islam berbeda dengan kegiantan ekonomi menurut system lainnya. Ekonomi Islam memiliki beberapa sifat yaitu: 
a. Kegiatan Ekonomi Islam dalam Islam bersifat pengabdian.

Nilai ini termasuk cara penerapan akidah yang umum yaitu: pekerjaan apa saja yang dilakukan oleh orang Islam, baik pekerjaan ekonomis maupun bukan, bisa saja berubah dari perkerjan materil bisa menjadi ibadat dan berpahala, apabila orang Islam itu bermaksud mengubah niatnya untuk mendapatkan keridaan Allah SWT. Hal ini sesuai dengan hadist Nabi SAW:

"Haddasana ( membicarakan pada kita) Abdullah Bin Salamah berkata : akhbarana ( memberitahukan pada kita) Malik'an Yahya Ibn Said'an Muhamad Ibn Ibrahim'an a-qomah Ibn Waqas'an Umar bahwasannya Rasullah SAW bersabda: segala kegiatan berdasarkan dengan niat dan setiap berkerjaan seseorang berdasarkan apa yang di niatkannya”. ${ }^{25}$

Hadis tersebut menjelaskan bahwa setiap perbuatan itu harus dilandasi dengan niat agar memiliki nilai pahala. Karena Islam memandang bahwa segala perbuatan itu, baik perbuatan dari ritual atau muamalah akan memiliki nilai pahal bila diniatkan untuk mengabdi kepada Allah. Niat agar memiliki nilai pahala. Karena Islam memandang bahwa segala perbuatan itu, baik perbuatan dari ritual atau muamalah akan memiliki nilai pahala bila diniatkan untuk mengabdi kepada Allah.

b. Kegiatan dalam Ekonomi Islam bercita-cita luhur.

Dalam system Ekonomi Islam keuntungan materil hanyalah sebagai berantara untuk menuju tujuan yang hakiki dan cita-cita lebih luhur yaitu untuk memakmurkan bumi dan membersiapkannya bagi kehidupan insani sebagai kepatuhan terhadap perintah Allah, serta sebagai realisasi khalifah dimuka bumi, karena ada suatu kepercayaan dan keyakinan bahwa manusia akan berhadapan dengan sang penciptanya untuk mempertanggungjawabkan segala perbuatannya.

2. Adanya keseimbangan antara kepentingan individu dan kepentingan masyarakat.

Dalam sistem Ekonomi Islam tidak mengenal bertentangan antara kepentingan individu dan kepentingan orang banyak, atau mengorbankan kepentingan individu demi kepentiangan orang banyak. Sistem Ekonomi Islam memiliki cara tersendiri yaitu memperhatikan dua kepentingan bersama dan berupaya memberikan keseimbangan antar keduanya. Islam mengakui kepentingan individu dan mengakui kepentingan orang banyak selama tidak ada bertentangan antara 
keduanya atau selama masih mungkin dipertemukan keduanya. Islam juga melarang monopoli barang dagangan, dengan cara menimbun dan menjualnya disaat harganya melambung tinggi, serta kebutuhan akan barang tersebut begitu mendesak. Dalam hal melayani juga komsumen harus sama kepentingannya dimata para karyawan yang memberikan pelayanan, tidak boleh sinis kepada satu dan ramah kepada yang lain. Semua memiliki kepentingan yang sama.

\section{Metode Penelitian}

Penelitian ini dilaksanakan di Panyabungan Mandailing Natal. Alasan memilih tempat tersebut adalah karena Panyabungan adalah pusat kota Mandailing Natal sebagai pusat perbelanjaan dan industri, perdagangan dan usaha masyarakat yang paling dominan bila dibandingkan dengan wilayah lain di Mandailing Natal. Adapun sumber data dari penelitian ini adalah karyawan dan konsumen sebagai sumber data primer, dan dokumen, buku sebagai sumber data sekunder. Adapun teknik pengumpulan data yang dipakai adalah angket, observasi, wawancara dan dokumentasi.

Analisis data yang digunakan adalah meteode deskriptif kualitatif yaitu dengan cara mengumpulkan data, dikelompokkan lalu disusun dan dihubungkan dengan teori yang relevan yang berhubungan dengan masalah yang dibahas untuk diambil suatu kesimpulan.

\section{Hasil dan Pembahasan}

Implementasi Etika Pelayanan Pada Mini Market Dan Swalayan Panyabungan Kabupaten Mandailing Natal Guna Mencapai Profit Yang Maksimal

Seluruh mini market atau swalayan yang disebutkan di atas adalah usaha yang bergerak dibidang penjualan kebutuhan bahan pokok seperti sembako, dan berbagai keperluan lainnya. Bahkan bahan makanan yang tahan lama juga dijual dalam jumlah yang besar. Mini Market di panyabungan sudah merupakan pasar semi modern, yang membedakan pasar dengan Mini Market adalah pada Mini Market pembeli dapat melayani diri sendiri dengan dapat memilih sendiri barang yang akan dibeli dan dilayani karyawan pada Mini Market tersebut.

Untuk mencapai target pencapaian laba bagi perusahaan tidak lepas dari pemberian pelayanan yang baik dan memuaskan kepada konsumen. Untuk meningkatkan keuntungan tersebut setiap karyawan dituntut untuk memiliki sikap 
melayani yang baik, maka indikator yang dipakai untuk melihat hasil akhir penelitian ini terdiri dari: Kejujuran dalam melayani, berbicara yang sopan, cekatan dalam melayani, ramah tamah dalam melayani, tidak berburuk sangka, melayani dengan penuh tanggung jawab, karyawan juga harus memiliki keinginan untuk menolong, melayani konsumen dengan baik tanpa pilih kasih, berpakaian yang rapi. ${ }^{26}$

Dari etika pelayanan yang diterapkan tersebut dapat dijelaskan bagaimana tanggapan konsumen terhadap etika pelayanan yang dilakukan karyawan pada setiap mini market yang ada tersebut:

\section{Kejujuran}

Responden setuju Kejujuran merupakan modal utama seseorang karyawan dalam melayani pelanggan, kejujuran tersebut meliputi kejujuran dalam berbicara bersikap maupun bertindak. Kejujuran inilah yang akan menimbulkan kepercayaan konsumen atas layanan yang diberikan. ${ }^{27}$

Tabel 2. Tanggapan Responden Tentang Kejujuran Karyawan Dalam Melayani

\begin{tabular}{|l|l|l|l|}
\hline \multirow{2}{*}{ No } & Tanggapan Responden & Frekuensi & Persentase \\
\hline 1 & Sangat baik & 75 & $75 \%$ \\
\hline 2 & Baik & 17 & $17 \%$ \\
\hline 3 & Cukup baik & 3 & $3 \%$ \\
\hline 4 & Tidak baik & 5 & $5 \%$ \\
\hline Jumlah & 100 & $100 \%$ \\
\hline
\end{tabular}

Berdasarkan tabel di atas responden menanggapi "kejujuran" dengan persentase $75 \%$ sangat baik. Artinya konsumen sangat mempercayai para karyawan sebagai orang sangat jujur dalam melayani konsumen. Data ini didukung dengan hasil wawancara dengan konsumen yang mengatakan mereka belum pernah dirugikan terkait materi apapun saat belanja, baik karena barangnya cacat, kedaluarsa maupun kekurangan pengembalian uang. Kejujuran salah satu upaya tersirat untuk mendapatkan hasil profit maksimal dan kepercayaan konsumen.

2. Berbicara yang sopan

Berbicara kepada pelanggan harus sopan, jelas dan tidak bertele-tele. Dengan suara yang lemah lembut dan ramah, sopan santun tutur kata. Komunikasi 
yang dilakukan diharapkan dapat membuat pelanggan tertarik dan terkesan terhadap apa yang dijual oleh perusahaan. Berikut tanggapan konsumen terhadap penerapannya:

Tabel 3. Tanggapan Responden Tentang Kesopanan Karyawan Dalam Berbicara Kepada Pelanggan

\begin{tabular}{|l|l|l|l|}
\hline No & Tanggapan Responden & Frekuensi & Persentase \\
\hline 1 & Sangat baik & 81 & $81 \%$ \\
\hline 2 & Baik & 15 & $15 \%$ \\
\hline 3 & Cukup baik & 2 & $2 \%$ \\
\hline 4 & Tidak baik & 2 & $2 \%$ \\
\hline Jumlah & 100 & $100 \%$ \\
\hline
\end{tabular}

Responden menanggapi sangat baik sebanyak $81 \%$, hal ini dapat sebagai pengakuan konsumen bahwa karyawan pada setiap pembelanjaan yang mereka kunjungi yang disebutkan di atas selalu sopan dan ramah.

\section{Cekatan}

Seorang karyawan dituntut untuk cekatan dalam bekerja dan tidak malas-malasan. Karyawan Mini Market harus segera atau cekatan memenuhi segala keingian konsumen dengan tidak membuang-buang waktu konsumen dalam menunggu barang yang diinginkannya. Berikut tanggapan konsumen terhadap penerapannya:

Tabel 4. Tanggapan responden Mengenai kecepatan melayani

\begin{tabular}{|l|l|l|l|}
\hline No & Tanggapan Responden & Frekuensi & Persentase \\
\hline 1 & Sangat baik & 75 & $75 \%$ \\
\hline 2 & Baik & 10 & $10 \%$ \\
\hline 3 & Cukup baik & 10 & $10 \%$ \\
\hline 4 & Tidak baik & 5 & $5 \%$ \\
\hline \multicolumn{2}{|l|}{ Jumlah } & 100 & $100 \%$ \\
\hline
\end{tabular}

Responden memberi tanggapan sebanyak $75 \%$ terkait kecekatan karyawan saat melayani konsumen, ini berarti karyawan benar sangat cekatan dalam melayani konsumen yang datang.

4. Melayani dengan ramah tamah

Bersikap lemah lembut dan ramah tamah merupakan salah satu etika pergaulan yang harus dipahami karyawan karena dengan bersikap lemah lembut dan ramah tamah dalam melayani konsumen akan membuat konsumen senang, 
Januari - Juni 2020: 72 - 96

Sebagai karyawan semestinya memahami betul apa itu politik senyum, senyum bagi karyawan diinstitusi manapun manjadi wajib hukumnya. Berikut tanggapan konsumen mengenai penerapannya:

Tabel 5. Tanggapan Responden Mengenai Keramah Tamahan Karyawan

\begin{tabular}{|l|l|l|l|}
\hline No & Tanggapan Responden & Frekuensi & Persentase \\
\hline 1 & Sangat baik & 61 & $61 \%$ \\
\hline 2 & Baik & 23 & $23 \%$ \\
\hline 3 & Cukup baik & 9 & $9 \%$ \\
\hline 4 & Tidak baik & 7 & $7 \%$ \\
\hline Jumlah & 100 & $100 \%$ \\
\hline
\end{tabular}

Responden sangat setuju karyawan di lokasi penelitian $61 \%$ Ramah dalam melayani konsumen yang datang dan membeli.

5. Tidak berburuk sangka kepada konsumen.

Dalam melayani pelanggan hendaknya seorang karyawan menghormati konsumennya, dengan cara memberi kebebasan pelanggan atau konsumen dalam memilih barang yang akan dibeli. Berikut tanggapan konsumen mengenai penerapannya:

Tabel 6. Tanggapan Responden Mengenai baik sangkanya karyawan

\begin{tabular}{|l|l|l|l|}
\hline No & Tanggapan Responden & Frekuensi & Persentase \\
\hline 1 & Sangat baik & 30 & $30 \%$ \\
\hline 2 & Baik & 45 & $45 \%$ \\
\hline 3 & Cukup baik & 15 & $15 \%$ \\
\hline 4 & Tidak baik & 10 & $10 \%$ \\
\hline \multicolumn{2}{|l|}{ Jumlah } & 100 & $100 \%$ \\
\hline
\end{tabular}

Responden mananggapi $45 \%$ baik dan $30 \%$ sangat baik, ini artinya responden sebagai konsumen setuju karyawan tidak berburuk sangka terhadap konsumen yang datang membeli dengan cara memilih sendiri barang yang diinginkannya.

6. Melayani dengan penuh tanggung jawab

Tanggung jawab adalah rasa tanggung jawab yang dimiliki oleh seorang karyawan terhadap pekerjaannya agar pekerjaannya mempunyai nilai guna. Setiap karyawan harus bertanggung jawab terhadap pekerjaannya, terutama melayani 
pembeli dengan serius dan sampai selesai atau tidak setengah-setengah. Berikut tanggapan konsumen terhadap penerapannya:

Tabel 7. Tanggapan Responden Mengenai Tanggungjawab Karyawan

\begin{tabular}{|l|l|l|l|}
\hline No & Tanggapan Responden & Frekuensi & Persentase \\
\hline 1 & Sangat baik & 25 & $25 \%$ \\
\hline 2 & Baik & 45 & $45 \%$ \\
\hline 3 & Cukup baik & 20 & $20 \%$ \\
\hline 4 & Tidak baik & 10 & $10 \%$ \\
\hline Jumlah & 100 & $100 \%$ \\
\hline
\end{tabular}

Responden menanggapi $45 \%$ baik dan $25 \%$ sangat baik, ini artinya karyawan bertanggungjawab dalam pekerjaannya melayani konsumen.

7. Karyawan juga harus memiliki keinginan untuk menolong

Keinginan untuk menolong misalnya menolong konsumen ketika mencari barang yang dibutuhkan dan menolong konsumen yang kesulitan membawa barang belanjaannya, dan menganggap bahwa pekerjaan yang dilakukan bukan semata-mata untuk kesenangan dunia saja tetapi juga untuk mengharapkan pahala dari Allah, pertolongan yang diberikan akan membuat konsumen merasa terkesan dengan pelayanan yang ada. Sikap tolong-menolong yang diterapkan dapat digambarkan dari keikhlasan karyawan membantu konsumen yang kesulitan membawa barang belanjaannya. Berikut tanggapan konsumen terhadap penerapannya:

Tabel 8. Tanggapan Responden Mengenai sikap menolong

\begin{tabular}{|l|l|l|l|}
\hline No & Tanggapan Responden & Frekuensi & Persentase \\
\hline 1 & Sangat baik & 35 & $35 \%$ \\
\hline 2 & Baik & 45 & $45 \%$ \\
\hline 3 & Cukup baik & 15 & $15 \%$ \\
\hline 4 & Tidak baik & 5 & $5 \%$ \\
\hline Jumlah & 100 & $100 \%$ \\
\hline
\end{tabular}

Responden menanggapi $45 \%$ baik dan $35 \%$ sangat baik terkait sikap menolong dari karyawan, ini berarti karyawan mau menolong konsumen.

8. Melayani konsumen dengan baik tanpa pilih kasih

Karyawan dituntut untuk dapat melayani konsumen dengan tidak membedakan kedudukan konsumen, pangkat dan umur konsumen, karyawan harus menganggap bahwa konsumen adalah Raja, manusia yang juga memiliki 
perasaan yang harus dijaga, jangan sampai konsumen merasa tidak dianggap. Berikut tanggapan konsumen terhadap penerapannya:

Tabel 9. Tanggapan Responden Mengenai Karyawan Melayani Baik Tanpa Pilih Kasih

\begin{tabular}{|l|l|l|l|}
\hline No & Tanggapan Responden & Frekuensi & Persentase \\
\hline 1 & Sangat baik & 63 & $63 \%$ \\
\hline 2 & Baik & 13 & $13 \%$ \\
\hline 3 & Cukup baik & 20 & $20 \%$ \\
\hline 4 & Tidak baik & 4 & $4 \%$ \\
\hline Jumlah & 100 & $100 \%$ \\
\hline
\end{tabular}

Responden menanggapi karyawan tidak pilih kasih 63\% sangat baik, 20\% cukup baik. Ini artinya sikap tidak pilih kasih sangat kecil ditunjukkan oleh karyawan. Karyawan mengganggap sama konsumen dalam memberikan pelayanan.

9. Berpakaian yang rapi

Dalam melayani konsumen karyawan harus selalu berpenampilan yang rapi dan sopan karena penampilan karyawan akan menunjukkan citra perusahaan dimata konsumen atau pelanggan. Berikut tanggapan konsumen terhadap penerapannya:

Tabel 10. Tanggapan Responden Mengenai Karyawan Berpakaian Rapi Saat Melayani

\begin{tabular}{|l|l|l|l|}
\hline No & Tanggapan Responden & Frekuensi & Persentase \\
\hline 1 & Sangat rapi dan sopan & 26 & $26 \%$ \\
\hline 2 & Rapi dan sopan & 40 & $40 \%$ \\
\hline 3 & Kurang rapi dan sopan & 25 & $25 \%$ \\
\hline 4 & Tidak rapi dan sopan & 9 & $9 \%$ \\
\hline Jumlah & 100 & $100 \%$ \\
\hline
\end{tabular}

$40 \%$ responden menyatakan karyawan sangat rapi dan sopan dalam berpakaian dan $26 \%$ sangat rapi dan sopan. Ini berarti karyawan yang melayani mayoritas rapi dan sopan dalam berpakaian.

Didukung oleh data wawancara, observasi dan data angket, indikator yang digunakan sebagai alat ukur implementasi etika pelayanan karyawan pada mini market dan swalayan di Panyabungan Mandailing Natal berada pada posisi sangat 
baik dalam memberikan pelayanan kepada konsuman dalam upaya mendapatkan profit yang maksimal.

\section{Tinjauan Ekonomi Islam Terhadap Implementasi etika pelayanan pada Mini} Market Dan Swalayan Panyabungan Kabupaten Mandailing Natal

Menjaga kepercayaan pelanggan untuk menjadi pelanggan tetap merupakan sesuatu yang mutlak dan harus dilakukan oleh setiap pedagang Mini Market di Panyabungan. Mini Market sebagai pusat perbelanjaan di Panyabungan harus memberikan pelayanan yang optimal agar pelanggan merasa nyaman sehingga pelanggan atau konsumen tetap setia menjadi konsumen serta bisa menarik calon pelanggan lainnya. Nilai-nilai adab, kesopanan dan tata krama harus ditunjukkan setiap melayani pelanggan atau konsumen. Hal-hal tersebut tidak terlepas dari nilai-nilai Ekonomi Islam, hakikatnya adalah setiap perkataan dan perbuatan khususnya dalam melayani pelanggan harus mencerminkan nilai-nilai Islam sehingga pelanggan dan karyawan tidak merasa menjadi pihak yang dirugikan.

Penerapan Etika pada oleh karyawan pada setiap mini market atau swalayan dalam rangka memberikan pelayanan kepada pelanggan ditinjau dari Ekonomi Islam, yaitu:

1. Jujur

Perilaku karyawan pada setiap Mini Market dan Swalayan di Panyabungan dapat dikatakan telah berlaku jujur dalam melayani konsumen dengan tidak menyembunyikan cacat pada barang. Mereka menjelaskan kondisi barang yang diambil oleh konsumen misalnya masalah tanggal kedaluarsa. Hal ini telah sesuai dengan syariah Islam.

\section{Sopan santun}

karyawan setiap Mini Market dan Swalayan di Panyabungan dalam melayani konsumen telah bersikap sopan santun. Dibuktikan dengan ketika mereka membacakan barang yang telah kita beli saat mereka menghitung harga dan jenisnya. Mereka menyapa konsumen dengan lembut dan bertata krama. Hal ini telah sesuai dengan syariah Islam.

\section{Cekatan atau Rajin}

Karyawan Mini Market dan Swalayan Panyabungan melayani konsumen dengan cekatan atau rajin. Karyawan dapat menghitung belanjaan konsumen 
dengan cepat dan melayani begitu banyaknya konsumen yang datang, kerajinan mereka ditunjukkan dengan kesediaan mereka menunggui kita saat dibutuhkan.

a. Ramah tamah

Karyawan Mini Market dan Swalayan Panyabungan melayani konsumen dengan ramah dan lemah lembut sehingga membuat para membuat pelanggan senang. Dan sebagian besar para karyawan memiliki budaya sikap yang baik, yaitu sikap tabassum (tersenyum) sehingga membuat para pelanggan merasa lebih dihargai.

b. Tidak berburuk sangka

Pada Mini Market dan Swalayan Panyabungan prinsip saling menghormati dapat digambarkan dari kebebasan konsumen dalam berlalu lalang dan memilih barang yang akan dibeli. Tidak pernah Nampak seorang karyawan terlalu memperhatikan CCTV dan penuh kecurigaan, mereka nampak luwes dan terkesan bahagia dengan kehadiran kita konsumen. Jika dilihat karyawan telah bersikap menghormati konsumennya.

c. Tanggungjawab

Berdasarkan hasil wawancara karyawan Mini Market dan Swalayan di Panyabungan adalah orang yang bertanggungjawab, ketika seorang konsumen salah membeli merek dan mengembalikannya kepada mini market, karyawan mini market justru mengganti dengan merek yang diinginkan oleh konsumen. Secara sepihak juga karyawan dianggap bertanggungjawab karena mereka menjaga took dan melayani konsumen dengan baik dan penuh tanggung jawab.

d. Karyawan juga harus memiliki keinginan untuk menolong

karyawan telah melaksanakan prinsip tolong menolong dalam konsumen ketika berbelanja, karena ketiak seorang konsumen mengalami kesulitan mencari barang yang ingin dibeli, karywan dengan senang hati menunjukkan dan mengambilnya untuk konsumen. karyawan harus memiliki sifat ikhlas dalam membantu. Hal ini sesuai dengan prinsip Ekonomi Islam.

e. Melayani konsumen dengan baik tanpa pilih kasih

Karyawan melayani konsumen dengan berlaku adil dengan tidak pilih-pilih konsumen dalam melayani. Sehingga pelanggan merasa diperlakukan dengan adil.

f. Cara berbusana 
Seluruh karyawan telah berpakaian yang rapi sesuai dengan syariah Islam. Dal ini juga didukung budaya Mandailing yang sangat religious. Islam bertujuan untuk membentuk masyarakat dengan tatanan sosial yang solid. Dalam tatanan itu, setiap individu diikat oleh persaudaraan dan kasih sayang bagai satu keluarga. Sebuah persaudaraan yang universal dan tak diikat batas geografis. Islam menganggap umat manusia sebagai satu keluarga yang mempunyai derajat yang sama dihadapan Allah. Secara sosial, nilai yang membedakan antara satu dengan yang lain adalah ketakwaan, ketulusan hati, kamampuan, dan pelayanannya pada kemanusiaan. $^{28}$

Didalam penerapan etika seluruh karyawan Mini Market dan Swalayan objek penelitian indicator etika yang diamalkan terdiri dari kejujuran, berbicara yang sopan, cekatan dalam melayani, ramah tamah dalam melayani, tidak berburuk sangka, mau menolong, melayani konsumen dengan baik tanpa pilih kasih, berbusana yang baik. Maka dapat disimpulkan penerapan etika pelayanan yang diimplementasikan sudah merupakan bagian dari prinsip Ekonomi Islam. Pengaruh yang baik dari pelayanan merupakan hal positif bagi perusahaan, sebab bila pelanggan merasa puas dengan pelayanan yang telah diberikan oleh karyawan maka pelanggan akan mempertahankan atau menjadi pelanggan tetap pada dan tentu akan meningkatkan profit bagi perusahaan. Dengan demikian, berdasarkan penjelasan-penjelasan di atas yang telah dipaparkan, tentang pelaksanaan etika pelayanan pada ke 10 Mini Market dan Swalayan tersebut, seluruh indikatornya telah dilaksanakan dengan baik sesuai dengan syariah Islam.

\section{Kesimpulan}

Etika pelayanan yang diimplementasikan pada Mini Market dan swalayan di Panyabungan guna mencapai profit yang maksimal didasarkan pada nilai-nilai pelayanan yang beradab beretika, melalui nilai-nilai kejujuran, berbicara yang sopan, cekatan, melayani dengan ramah tamah, tidak berburuk sangka kepada konsumen, melayani dengan penuh tanggung jawab, karyawan juga menerapkan sikap suka menolong, Melayani konsumen dengan baik tanpa pilih kasih dan berpakaian yang rapi. Semua item indikator ini adala instrumen yang disetujui oleh responden sendiri. Tinjauan Ekonomi Islam terhadap implementasi etika pelayanan pada Mini Market dan swalayan di Panyabungan Mandailing Natal telah sesuai dengan prinsip ekonomi Islam yang menuntut adanya keadilan dan 
keseimbangan dalam setiap pengamalannya. Keadilan, keseimbangan, jujur, tolong menolong atau nilai maqasid syariah lainnya sebagai nilai ekonomi islam telah terlaksana dengan indikator tersebut di atas, semuanya telah sesuai dengan prinsip pelaksanaan nilai-nilai ekonomi Islam atau syariat Islam.

Endnote II, h. 557

${ }^{2}$ Fandy, Tjiptono, Service Manajement, (Yogyakarta: CV. Andi Offset, 2008), h. 1

${ }^{3}$ Fandy, Tjiptono, Prinsip-Prinsip Total Quality Service, (Yogyakarta: C.V Andi Offset, 2005), h. 128

${ }^{4}$ Philip,Kotler, Manajemen Pemasaran, (Indonesia: PT. Macanan Jaya Cemerlang, 2007), h. 54

${ }^{5}$ Badan Pusat Statistik Mandailing Natal (mandailingnatalkab.bps.go.id, diakses pada 09 Maret 2020 Pukul 22.10 WIB.

${ }^{6}$ Mudlar Ahmad, Etika Dalam Islam, (Semarang: Ikhlas, th), Cet. Ke-1, h. 15

${ }^{7}$ Kasmir, Etika Customer Service, (Jakarta: Bumi Aksara. 2008), h., 79

${ }^{8}$ Sudarsono, Etika Islam Tentang Kenakalan Remaja, (Jakarta: Rineka Cipta, 1993), cet. $\mathrm{Ke}-3$, h. 40-41

${ }^{9}$ Kasmir, Kewirausahaan, (Jakarta: Bumi Aksara. 2008), h. 275

${ }^{10}$ Philip,Kotler, Manajemen Pemasaran, (Indonesia: PT. Macanan Jaya Cemerlang, 2007), h. 50 $148-151$

${ }^{11}$ Burhanuddin Abdullah, Budaya Kerja Perbankan, (Jakarta: LP3ES, 2006), cet. ke-1, h.

${ }^{12}$ Kasmir, Etika Customer Service, (Jakarta: Bumi Aksara. 2008), h., 56

${ }^{13}$ Didin Hafidhuddin dan Hendri Tanjung, Manajemen Syariah Dalam Praktik, (Jakarta: Gema Insani, 2003), cet.1, h. 59

${ }^{14}$ Ibid

${ }^{15}$ Sinambela, Reformasi Pelayanan Publik, (Jakarta: Bumi Aksara. 2007), h. 6

${ }^{16}$ Muhandis Natadiwirya, Etika Bisnis Islam, (Jakarta : Granada Press, 2007), h. 66

${ }^{17}$ Kasmir, Op.cit, h. 78-80

${ }^{18}$ Muhammad, Pengantar Akuntansi Syariah, (Jakarta: PT: Gramedia Pustaka, 1999), cet. Ke-1, h. 591

${ }^{19}$ Muhammad Syakir Sula, Asuransi Syariah (Life and General), (Jakarta: Gema Insani, 2004), h. 747

${ }^{20}$ Ibid, 748

${ }^{21}$ Kasmir, Op.cit, h. 93

${ }^{22}$ Adiwarman Karim, Ekonomi Mikro Islami (Jakarta: III T, 2002),h.17

${ }^{23}$ An Nabhani Taqiyyudin, Membangun SistemEkonomi Alternatif Prespektif Islam,Risalah Gusti, Surabaya, 2002

${ }^{24}$ Ahmad Muh Al-Assal dan Fathi Ahmad abd Karim, Sistem Prinsip dan Tujuan Ekonomi Islam, Terj Imam Saefuddin, (Bandung: Pustaka Setia, 1999)

${ }^{25}$ Imam Al- Bukhori. Shaheh Al-Bukhori, (Beirut: Dar al Al-kutub Al-Ilmiyah. 1992), Jilid 1, hal. 24

${ }^{26}$ Indikator ini juga dipaparkan oleh beberapa pemilik mini market bahwa mereka juga mengamal hal tersebut.

${ }^{27}$ Hasil Wawancara dengan responden pada 8 Juni 2020

${ }^{28}$ Muhammad Syafii Antonio, Op.cit., h.13-14

\section{DAFTAR PUSTAKA}

Abdullah, Burhanuddin. 2006. Budaya Kerja Perbankan. Jakarta: LP3ES. 
Jureid: Implementasi Etika Pelayanan Pada Mini Market $\mid 95$

Ahmad, Muh Al-Assal dan Fathi Ahmad abd Karim. 1999. Sistem Prinsip dan Tujuan Ekonomi Islam. Terj Imam Saefuddin. Bandung: Pustaka Setia.

Al- Bukhori, Imam. 1992. Shaheh Al-Bukhori. Beirut: Dar al Al-kutub AlIlmiyah.

An-Nabhani, Taqiyyudin. 2002. Membangun Sistem Ekonomi Alternatif Prespektif Islam. Surabaya: Risalah Gusti.

Antonio, Muhammad Syafii. 2001. Bank Syariah dari Teori ke Praktik. Jakarta: Gema Insani.

At-Tirmidzi. 1997. Shahih Sunan At-Tirmidzi . Beirut: Dar- Al Kotob Al-Ilmiyah.

Badan Pusat Statistik Mandailing Natal mandailingnatalkab.bps.go.id. diakses 09 Maret 2020.

Bekum, Rafik Issa. 2004. Etika Bisnis Islami Terj Muhammad. Yokyakarta: Pustaka Pelajar.

Hafidhuddin, Didin dan Hendri Tanjung. 2003. Manajemen Syariah Dalam Praktik .Jakarta: Gema Insani.

Hamid, Arifin. 2007. Hukum Ekonomi Islam. Bogor: Ghalia Indonesia.

Karim, Adiwarman. 2002. Ekonomi Mikro Islami. Jakarta: III T

Kasmir. 2008. Etika Customer Service. Jakarta: Bumi Aksara. .2008. Kewirausahaan. Jakarta: Bumi Aksara.

Kotler, Philip. 2007. Manajemen Pemasaran. Indonesia: PT. Macanan Jaya Cemerlang.

Muhammad. 1999. Pengantar Akuntansi Syariah. Jakarta: PT: Gramedia Pustaka. 
96 AT-TAWASSUTH: Jurnal Ekonomi Islam, Volume V No. 1 Januari - Juni 2020: 72 - 96

Muhammad. 2002. Visi Alquran Tentang Etika dan Bisnis. Jakarta: Salemba Diniyah.

Muslim, Imam. 1997. Shaheh Muslim. Beirut:-lebanon: Dar al Al-kutub AlIlmiyah.

Natadiwirya, Muhandis. 2007. Etika Bisnis Islam. Jakarta: Granada Press.

Qardhawy, Yusuf. 1997. Norma dan Etika Okonomi Islam.. Jakarta: Gema Insani.

Said Sa'ad Marthon. 2004. Ekonomi Islam ditengah krisis ekonomi global. Jakarta: Zikrul Hakim.

Said. 2008. Pengantar Ekonomi Islam. Pekanbaru: Suska Press.

Sinambela. 2007. Reformasi Pelayanan Publik. Jakarta: Bumi Aksara.

Sudarsono. 1993. Etika Islam Tentang Kenakalan Remaja. Jakarta: Rineka Cipta.

Sula, Muhammad Syakir. 2004Asuransi Syariah Life and General. Jakarta: Gema Insani.

Tjiptono, Fandy. 2005. Prinsip-Prinsip Total Quality Service. Yogyakarta: C.V Andi Offset.

Tjiptono, Fandy. 2008. Service Manajement. Yogyakarta: CV. Andi Offset. 